\title{
Recurrent Mucocutaneus Aspergillosis in Dock8-Deficient Patient
}

\author{
Yaryna Romanyshyn ${ }^{1 *}$ and Larysa Kostyuchenko ${ }^{1,2}$ \\ ${ }^{1}$ Department of Pediatrics, Western-ukrainian specialized children's medical centre, Ukraine \\ ${ }^{2}$ Department of Clinical Immunology and Allergology, Lviv National Medical University, Ukraine
}

Submission: December 13, 2019; Published: January 08, 2020

*Corresponding author: Yaryna Romanyshyn, Department of Pediatrics, Western-ukrainian specialized children's medical centre, Lviv, Ukraine

Abstract

We report a case of DOCK8 deficiency, presenting severe fungal infection and a neuroblastoma. Male patient suffered severe eczema plus respiratory and ear infections from age 1 month. Aged 5 years a neuroblastoma was diagnosed and from age 6 years recurrent mucocutaneous aspergillosis with persistent leukocytosis, hyper eosinophilia, increased IgE level up to $25000 \mathrm{IU} / \mathrm{ml}$, low IgM and gradual decreasing T cell count were observed. Hyper IgE syndrome was considered and genetic testing revealed a large deletion of the DOCK8-gene.

Keywords: Immunodeficiency; Dock8; Deficiency; Aspergillosis

\section{Introduction}

Dedicator of cytokinesis 8 (DOCK8) deficiency is a primary immunodeficiency characterized by recurrent bacterial, viral and/or fungal infections, atopic dermatitis and food allergies.

\section{Case Report}

We report a 16-year-old male child with DOCK8 deficiency who had an unusual presentation and clinical course. He presented to our general pediatricians age 6 years with persistent severe atopic dermatitis from age 1 month, followed by recurrent purulent otitis episodes. Aged 7 months he had a severe Salmonella infection. There was no reported consanguinity. He has an older healthy sister, but his paternal uncle died at age 5 years, reason unknown. Aged 5 years an adrenal neuroblastoma stage II was diagnosed and the boy received surgery and chemotherapy as per the NB-97 treatment protocol. From age 6 to 11 years, he suffered pneumonia 2-3 times per year, chronic otitis and frequent skin infections. Cutaneous Aspergillus infections began during chemotherapy when aged 6 years (Figure 1), the lesions had a permanent exudation leading to severe hypoproteinemia (total protein-35-40g/l) and pus-like crusts. Voriconazole therapy was temporarily effective but disseminated invasive aspergillosis with bilateral interstitial pneumonia occurred one month later. On this occasion, intravenous Caspofungin led to complete symptoms resolution. From age 7 to 11 years our patient had recurrent episodes of mucocutaneous aspergillosis with progressive development of resistance to itraconazole, amphotericin B, voriconazole, and Caspofungin (Figures 2,3), only responding to posaconazole. Recurrent chronic paronychia was also observed. During this period he had a persistent leukocytosis $\left(22-25 \times 10^{9} / \mathrm{l}\right)$ and a marked hyper eosinophilia of $50-80 \%$ in his CBC. There was no lymphopenia and lymphocyte subclasses were within the agerelated normal range at the beginning with gradual decrease in $\mathrm{T}$ cells count with patient's age (Table 1). Initial Ig G, A and M were normal with IgE up to 25,000IU/ml. However, IgM declined with time to $33,7 \mathrm{mg} / \mathrm{dl}$. On the basis of his eczema, skin and pulmonary infections, early-onset malignancy, very high $\operatorname{IgE}$, and persistent hyper eosinophilia, Hyper IgE syndrome (HIES) was diagnosed. Ultimately, genetic testing showed a large deletion of exons 6-16 in the DOCK8-gene (M.H Albert et al, Kinderspital, LudwigMaximilians-University, München, Germany). Age 11 years he received a matched unrelated bone marrow in Italy (Spedali Sivili Brescia). Nine months post-transplant he developed progressive multifocal leukoencephalopathy due to Polyomavirus JC. Antivirals were ineffective and Cyclosporin A was stopped leading to they detected decreasing blood Polyomavirus JC, no further CNS deterioration on MRI, improvement in immunological status and stable donor chimerism 100\%. Currently he has good restoration of immunity, no infections and a healthy skin. 


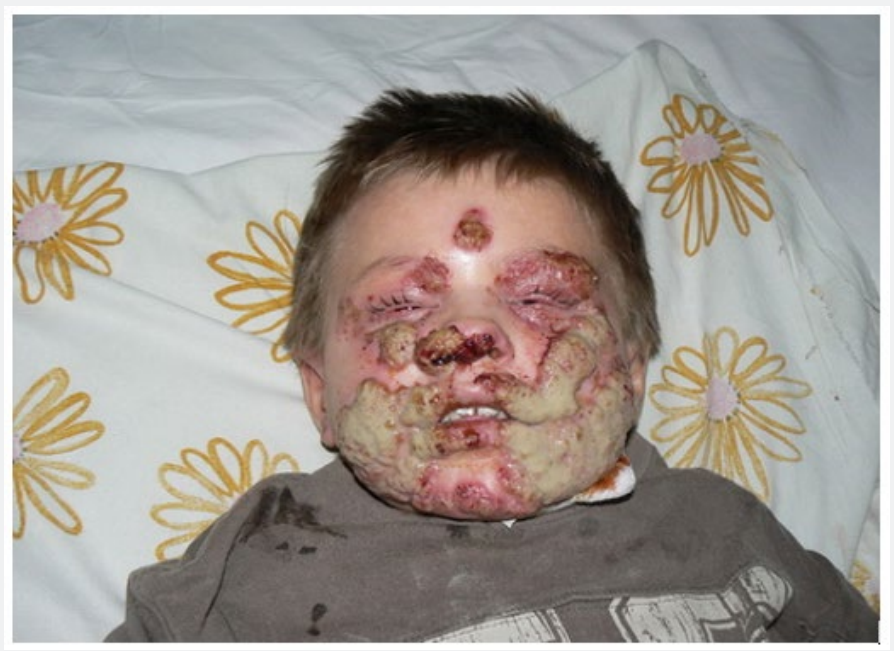

Figure 1:

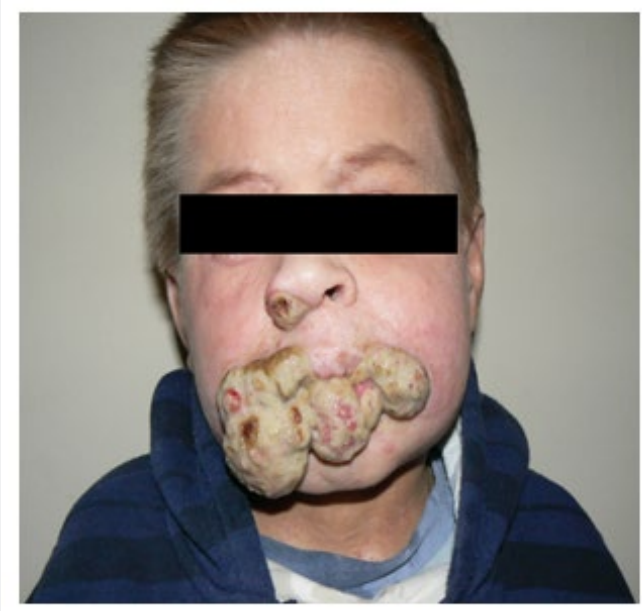

Figure 2:

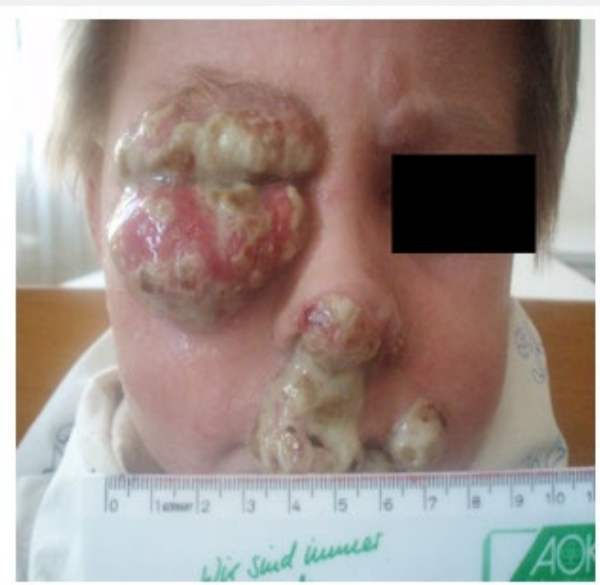

Figure 3: 
Table 1:

\begin{tabular}{|c|c|c|c|c|c|c|c|}
\hline \multirow[t]{2}{*}{ Date } & \multicolumn{2}{|c|}{20.10 .08} & \multicolumn{2}{|c|}{9.12 .08} & \multicolumn{2}{|c|}{ 2.03.10 } & \multirow{2}{*}{$\begin{array}{c}\begin{array}{c}\text { Normal values } \\
(5-10 y)\end{array} \\
\times 10^{9} / 1\end{array}$} \\
\hline & (\%) & $\mathbf{x 1 0}{ }^{9} / 1$ & (\%) & $\times 10^{9} / 1$ & $\%$ & $\times 10^{9} / 1$ & \\
\hline Lymphocytes & & 2,29 & & 1,64 & & 1,28 & \\
\hline CD3+T-cells & 50 & 1,16 & 54 & 0,89 & 40 & 0,51 & $0,7-4,2$ \\
\hline CD4+T-cells & 25 & 0,57 & 24 & 0,39 & 18 & 0,23 & $0,3-2,0$ \\
\hline CD8+T-cells & 17 & 0,39 & 22 & 0,36 & 17 & 0,22 & $0,3-1,8$ \\
\hline CD19+B-cells & 38 & 0,87 & 35 & 0,57 & 32 & 0,41 & $0,2-1,6$ \\
\hline NK-cells (CD16/56+) & 21 & 0,48 & 10 & 0,16 & 9 & 0,12 & $0,09-0.9$ \\
\hline
\end{tabular}

\section{Discussion and Conclusion}

Mutations in the dedicator of cytokinesis 8 gene (DOCK8) cause a combined primary immunodeficiency that is characterized by elevated serum IgE levels, depressed IgM levels, eosinophilia, sinopulmonary infections, cutaneous viral infections, and lymphopenia [1]. DOCK8 is a member of the DOCK180-related family of atypical guanine nucleotide exchange factors, which have been shown to have roles in actin cytoskeletal rearrangement. Because of this, the DOCK180 family members are involved in diverse biological processes that include cell migration, polarization, phagocytosis, fusion, and morphogenesis [2]. Immunological features of DOCK8 deficiency include: lymphopenia with low levels of $\mathrm{CD} 4+, \mathrm{CD} 8+$, and decreased production of antiviral cytokines INF,TNF; impaired generation of a durable secondary antibody response to specific antigens. Patients with this syndrome were also shown to have impaired Th17 cell development [3]. DOCK8 deficiency is very rare, estimated to be found in less than one person per million [4]; a total of 136 patients currently reported [5].These patients are also known to be at high risk for malignancies including squamous cell carcinoma, cutaneous T cell lymphoma/leukemia, and Burkitt lymphoma [6]. They are also characterized by CNS symptoms caused by CNS vasculitis and infection. But the hallmark of DOCK8 deficiency are severe cutaneous viral infection often caused by HSV, HPV, HZV, and molluscum contagiosum virus [6,7]. Initially, the disease was called autosomal recessive hyper IgE syndrome (AR-HIES) and considered a rare form of HIES, a primary immune deficiency disorder [8]. In 2009 however, National Institute of Allergy and Infectious Diseases (NIAID) researchers discovered that many cases of AR-HIES are caused by a separate disease that results from mutations in the DOCK8 gene $[9,10]$. As a result, the disease was renamed DOCK8 deficiency [11]. Our case highlights the increasing number of complications that can present in DOCK8-deficient patients not only severe viral infection and lymphomas, but fungal infection and neuroblastoma [12,13].

\section{References}

1. Chu EY, Freeman AF, Jing H, Cowen EW, Davies J et al. (2012) Cutaneous Manifestations of DOCK8 Deficiency Syndrome. Arch Dermatol 148(1): 79-84.

2. Jyonouchi H (2015) Hyperimmunoglobulinemia E (Job) Syndrome.

3. Helen C Su (2010) DOCK8 (Dedicator of cytokinesis 8) deficiency. Curr Opin Allergy Clin Immunol 10(6): 515-520.

4. (2015) Orphanet: Combined immunodeficiency due to DOCK8 deficiency.

5. Aydin SE, Kilic SS, Aytekin C, Kumar A, Porras O, et al. (2015) DOCK8 deficiency: clinical and immunological phenotype and treatment options - a review of 136 patients. J Clin Immunol 35(2):189-198.

6. Yong PF, Freeman AF, Engelhardt KR, Holland S, Puck JM, et al. (2012) An update on the hyper-IgE syndromes. Arthritis Res Ther 14(6): 228.

7. Qian Zhanga, Jeremiah C Davis, Christopher G Dove, Helen C Su (2010) Genetic, clinical, and laboratory markers for DIDS. Disease Markers 29(2010): 131-139.

8. (2017) National Institute of Allergy and Infectious diseases. DOCK8 deficiency.

9. (2012) DOCK8 deficiency as a rare variant of Hyper IgE syndrome (clinical case) (ESID Prague Spring Meeting, Praque (Czech Republic).

10. (2014) DOCK8 deficiency: a single unique case, $100^{\text {th }}$ J-Project Meeting.

11. I Romanyshyn, L Kostyuchenko, I Savchak (2014) Dock8 Deficiency: A Single Unique Case. J Clin Immunol 34: 721.

12. (2016) Mucocutaneus aspergillosis associated with DOCK8 deficiency, $2^{\text {nd }} J$-Project Congress.

13. (2017) Dock8 deficiency-clinical case, $4^{\text {th }}$ Workshop on Diagnostics of Immunodeficiencies. 
This work is licensed under Creative

Commons Attribution 4.0 Licens

DOI: 10.19080/AJPN.2020.08.555802
Your next submission with Juniper Publishers will reach you the below assets

- Quality Editorial service

- Swift Peer Review

- Reprints availability

- E-prints Service

- Manuscript Podcast for convenient understanding

- Global attainment for your research

- Manuscript accessibility in different formats ( Pdf, E-pub, Full Text, Audio)

- Unceasing customer service

Track the below URL for one-step submission https://juniperpublishers.com/online-submission.php 